\title{
Pandangan Pendidikan Kecerdasan Majemuk dalam Islam
}

\author{
Sunenti \\ Universitas Islam Negeri (UIN) Prof. KH. Saifuddin Zuhri \\ sunenti69@gmail.com \\ Tutuk Ningsih \\ Universitas Islam Negeri (UIN) Prof. KH. Saifuddin Zuhri \\ tutukningsih@gmail.com \\ Sunhaji \\ Universitas Islam Negeri (UIN) Prof. KH. Saifuddin Zuhri \\ a.sunhaji@iainpurwokerto.ac.id
}

\begin{abstract}
Islam recognizes that every human being has the best nature or nature. Here is where this longstanding trend needs dynamic support so that it can be properly honed. This type of research is library research and is a qualitative descriptive study. Based on the researcher's analysis, this study found that Islam has an inclusive view of multiple intelligences. The view of multiple intelligences affirms that every buman being has a natural nature and is a sign of a perfect buman being created by God.
\end{abstract}

Keywords: View, Multiple Intelligence, Islam

Abstrak: Islam mengakui bahwa setiap manusia memiliki fitrah atau pembawaan yang terbaik. Di sinilah kecenderungan yang telah lama ada ini membutuhkan dukungan yang dinamis sehingga dapat terasah dengan baik. Jenis penelitian ini adalah penelitian pustaka (library research) dan merupakan kajian deskriptif kualitatif. Berdasarkan analisis peneliti, kajian ini menemukan bahwa Islam memiliki pandangan inklusif tentang kecerdasan majemuk. Pandangan kecerdasan majemuk mengafirmasi bahwa setiap manusia memiliki fitrah dan merupakan tanda insan kamil atau manusia sempurna yang diciptakan Tuhan.

Kata Kunci: Pandangan, Kecerdasan Majemuk, Islam

Belajea: Jurnal Pendidikan Islam Vol. 6, No 2, 2021; 195-202

p-ISSN 2548-3390; e-ISSN 2548-3404, DOI: 10.29240/belajea.v6i2.2709

available online at:http://journal.staincurup.ac.id/indek.php/belajea 


\section{PENDAHULUAN}

Setiap manusia itu unik dan beragam. Oleh karena itu, alam semesta memiliki beragam jenis makhluk hidup. Dari jenis tumbuhan dan pepohonan, alam memberikan gambaran aneka ragam. Dari jenis binatang, alam juga menunjukkan adanya beragam binatang mulai dari pemakan tumbuhan hingga pemakan daging. Bahkan mereka memiliki daya bertahan dan menyerang yang berbeda-beda. Jenis manusia, sekalipun sepintas hanya memiliki perbedaan pada postur dan wajah. Ia menyimpan rahasia potensi yang tidak dimiliki tumbuhan dan binatang. Manusia bisa memiliki karakter keduanya diwaktu yang berbeda bahkan bersamaan. Di sinilah keunikan manusia menjadi hal menarik untuk dikaji, termasuk kajiannya dalam level kecerdasan.

Pandangan tentang beragamnya kecerdasan yang dimiliki manusia memberikan kemudahan tersendiri dalam menerapkan tujuan pendidikan secara individu dan kelompok. Meskipun pandangan kecerdasan oleh masyarakat cenderung masih menggunakan ukuran matematis. Namun, perlahan hal ini memiliki perkembangan tentang pemahaman tentang kecerdasan.

Dalam Islam, kecerdasan menjadi sesuatu yang diutamakan. Bahkan kecerdasan menjadi salah satu karakter yang harus dimiliki Nabi. Di sinilah kecerdasan memiliki peran penting dalam memberikan dan mengarahkan peradaban manusia. Salah satu teori populer yang berkembang adalah pemahaman tentang kecerdasan majemuk. Kecerdasan majemuk sebagai teori yang berkembang ini menjadi kajian yang menarik untuk selalu didiskusikan dan diteliti ulang oleh intelektual dan para pelajar. Hal ini memberikan gambaran antusiasme yang tinggi pada teori tersebut. Berbagai kalangan dari peneliti, guru dan cendikiawan berupaya merespon teori yang telah berkembang lama ini. Islam sebagai agama yang menjunjung tinggi pengetahuan berupaya memahami tentang kecerdasan majemuk yang dipopulerkan Howard Gardner.

Kajian ini merupakan penelitian deskriptif kualitatif dengan pendekatan fenomenologi. Pendekatan ini digunakan untuk mengungkapkan pengalaman individual secara deskriptif. ${ }^{1}$ Penelitian ini menggunakan studi pustaka untuk mendalami kajian dan memperoleh temuan yang relevan.

Di sinilah peneliti berusaha mengkaji pandangan pendidikan kecerdasan majemuk dalam pandangan Islam.

\footnotetext{
${ }^{1}$ Imam Gunawan,. Metode Penelitian Kualitatif Teori dan Praktik. Jakarta: Bumi Aksara.
} 2014. 


\section{PEMBAHASAN}

\section{Tentang Kecerdasan Majemuk}

Pandangan Gardner mengenai kecerdasan manusia sebagai suatu yang majemuk dan bukan tunggal. Ia memandang bahwa kemampuan seseorang tidak saja memiliki ukuran dengan penawaran pada jawaban yang terdapat pada ruang pembelajaran saja. Kecerdasan pada diri manusia menurut Gardner memiliki beberapa kriteria di antaranya; a) kemahiran dan kelihaian seseorang dalam menyelesaikan persoalan di kehidupan b) kemahiran untuk mengidentifikasi persoalan dan penemuan solusinya c) kemahiran dalam membuat suatu hal yang baru dan segan dalam menghargai seseorang. ${ }^{2}$

Gardner menyebut kecerdasan sebagai kapasitas. Kapasitas yang dimaksud adalah sebagai kemampuan seseorang dalam memproses sesuatu menjadi pemecahan persoalan secara terkordinasi.

Demikian Gardner mendefinisikan kecerdasan, lebih lanjut ia mengungkapkan bahwa semua manusia memiliki kemampuan setidaknya tujuh bahkan lebih cara-cara untuk memperoleh pengetahuan. Demikianlah, banyaknya definisi kecerdasan, sesuai dengan banyaknya jenis-jenis kecerdasan itu sendiri. Inilah juga yang mengantarkan Gardner pada kesimpulan bahwa kecerdasan manusia itu tidak tunggal, tapi majemuk, bahkan tak terbatas. Teori itulah yang kemudian dikenal dengan kecerdasan majemuk (multiple intelligences). Jenis kecerdasan tersebut adalah (1) kecerdasan bahasa, (2) kecerdasan matematika dan logika, (3) kecerdasan visual-spasial, (4) kecerdasan musikal-ritmik, (5) kecerdasan kinestetis (tubuh), (6) kecerdasan interpersonal (relasi), (7) kecerdasan intrapersonal, (8) kecerdasan naturalis (alam), dan (9) kecerdasan eksistensial

Sehingga secara bahasa Multiple Intelligences bisa menjadi pengertian dengan kecerdasan ganda. Ada juga yang mengartikannya dengan Kecerdasan Beragam. Dalam bahasa Indonesia kemudian intelligence diserap menjadi intelligensi yang bermakna capacity for learning, reasoning, and understanding (kapasitas belajar, beralasan dan memahami). Secara operasional kecerdasan dimaknai dengan kemahiran seseorang dalam mengkordinasi secara cepat atas apa yang dipelajarinya dengan tindakan dalam penemuan solusi. Pandangan M Noor HS juga menganggap bahwa kecerdasan sebagai kemahiran seseorang yang luar

\footnotetext{
2 Imam Machali. "Dimensi Kecerdasan Majemuk Dalam Kurikulum 2013”. Insania, Vol. 19, No. 1, Januari - Juni (2014).
} 
biasa dari rata-rata dengan keterampilan tinggi untuk menemukan persepsi atas apa yang diamati seseorang.

Gardner juga menjelaskan keterampilan tersebut sama halnya dengan kapasitas seseorang. Ia menyebut kapasitas inilah yang memiliki peluang untuk berkembang yang juga terhubung dengan pola asuh dan pendidikan yang dimiliki. Demikian Gardner mendefinisikan kecerdasan, lebih lanjut ia mengungkapkan bahwa semua manusia memiliki kemampuan setidaknya tujuh bahkan lebih cara-cara untuk memperoleh pengetahuan.

Pada awal penelitian (1983), Howard Gardner hanya menemukan tujuh macam kecerdasan, namun seiring berjalannya waktu, terdapat dua macam kecerdasan majemuk yang akhirnya dia temukan, sehingga berjumlah menjadi sembilan macam kecerdasan. ${ }^{3}$ Adapun kecerdasan-kecerdasan tersebut antara lain adalah:

\section{Kecerdasan Linguistik}

Kemampuan ini cenderung memiliki kepekaan yang tinggi terhadap katakata, aturan kata dan dapat mengekspresikan bahasa dengan lebih baik dari pada yang lain.

\section{Kecerdasan Logis-Matematis}

Kemampuan ini memiliki kepekaan terhadap angka, logika dan dapat melakukan penalaran dengan lebih baik.

\section{Kecerdasan Spasial-Visual}

Kemampuan ini banyak dimiliki pada orang yang memiliki kepekaan tinggi pada konsep ruang, letak atau bentuk.

\section{Kecerdasan Kinestetik-Jasmani}

Kemampuan ini dimiliki pada orang yang mapan dalam mengkordinasikan gerak tubuh yang lebih baik.

\section{Kecerdasan Musik}

Kemampuan mengenali irama, ritme dan nada ini menjadi kecenderungan bagi orang yang memiliki kecerdasan musik.

\section{Kecerdasan Interpersonal}

\footnotetext{
${ }^{3}$ Risydah Fadilah. "Pendidikan Islam Dan Kecerdasan Majemuk (Multiple Intelligence)". Al-Irsyad: Jurnal Pendidikan dan Konseling Vol. 9, No. 2, Juni-Desember (2019)
} 
Kemampuan untuk menjalin dan memerlihara hubungan sosial dan perasaan dengan yang lain ini menjadikan kecenderungan yang dimiliki orang yang memiliki kecerdasan interpersonal.

\section{Kecerdasan Intrapersonal}

Kemampuan memahami diri sendiri dan bertindah berdasarkan pemahaman. Hal ini sering dimiliki oleh ahli filsafat.

\section{Kecerdasan Naturalis}

Kemampuan mengenali flaura dan fauna.

\section{Kecerdasan Eksistensial}

Kemampuan menempatkan diri dalam wilayah kosmos yang tak terbatas. Orang yang memiliki kecerdasan ini menaruh perhatian yang dalam pada masalah hidup.

\section{Pandangan Islam Tentang Kecerdasan Majemuk}

Izzati menjelaskan terdapat juga pengembangan kecerdasan pada pendidikan Islam yakni berupa;

Tarbiyah imaniyah, yakni pandangan Islam yang mengarahkan pada kemampuan memahami, meyakini domain spiritual. Tarbiyah kbuluqiyah, yakni pandangan yang mengarahkan pada pembentukan kemampuan dalam memproses kepribadian, adab yang dilakukan setiap hari. Tarbiyah Jismiyah, sebagai kemampuan untuk memahami dan melakukan praktik baik dalam memelihara kondisi jasmani seseorang. Tarbiyah Aqliyah, yakni memberikan kemampuan untuk memahami bahwa manusia memiliki akal budi yang dapat dieksplorasi dengan lebih mapan. Tarbiyah nafsiyah, yakni pemahaman mengenai keberadaan jiwa yang dimiliki seseorang. Tarbiyah Ijtimaijah, sebagai pandangan untuk memahami bahwa manusia memiliki kemampuan dan kepekaan sebagai makhluk sosial. ${ }^{4}$

Shalih Abdul Aziz menjelaskan bahwa pendidikan jasmaniyah, 'aqliyah, khuluqiyah dan ijtima'iyah sebagai bagian dari tarbiyah yang berarti memiliki pengarahan potensi pada seseorang. ${ }^{5}$

Menurut Sarnoto, tidak ditemukan istilah Multiple Intelligences atau kecerdasan majemuk dalam Islam, namun memiliki kesamaan dengan

${ }^{4}$ H Izzati - . Potensi Pembelajaran Manusia: Perspektif Neurosains Dan Islam. Alifbata: Jurnal Pendidikan Dasar, 2021

${ }^{5}$ Jasminto, Konsep Pendidikan Anak Perspektif Fredrich Froebel, Proceedings Ancoms 2017- UNHASY Tebuireng Jombang. 
pandangan bahwa manusia terlahir fitrah ${ }^{6}$. alam Kamus Bahasa Indonesia Pusat Bahasa, kata fitrah diartikan dengan sifat asal, kesucian, bakat, pembawaan. Seakar dengan kata fitrah yaitu fitri bermakna kesederhanaan, dan hal yang tidak dibuat-buat (natural). Dari beberapa pengertian tersebut secara umum makna kata fitrah beragam, di antaranya adalah: fitrah dalam artian kejadian awal, bentuk awal, kemampuan dasar, potensi dasar, suci, agama, ciptaan, dan perangai. Dalam Islam juga ditemukan bahwa pembentukan agama seseorang dibentuk dari ayah dan ibunya. Dalam hal ini orang tua adalah orang yang paling dekat di lingkungan seseorang.

Pandangan ini menguatkan bahwa seseorang memiliki pembawaan awal atau yang populer disebut sebagai potensi. Namun, hal ini didukung pula pada lingkungan terdekatnya.

Demikian juga Al Ghazali memaknai fitrah sebagai dasar yang dibawa manusia sejak lahir dengan memiliki berbagai keistimewaan, di antaranya: Beriman kepada Allah SWT, menerima kebaikan atau menerima pendidikan, rasa ingin tahu dalam mencari kebenaran yang menuntut untuk berpikir, dorongan biologis, nafsu, dan watak, serta kekuatan lain dan sifat-sifat manusia yang bisa dikembangkan dan dapat disempurnakan. Fitrah juga berarti potensi dasar untuk mengabdi dan bermarifat kepada Allah Swt. Sebagaimana Ibnu Katsir yang memaknai fitrah dengan ma'rifatullah dan mengakui keesaanNya atau taubid.

Penciptaan manusia jika merujuk makna fitrah sebagai sebuah penciptaan, maka dalam beberapa ayat Al Quran disebutkan bahwa manusia diciptakan dengan sebaik-baik bentuk, sebagaimana firmanNya

"Sunggub kami ciptakan manusia dalam bentuk terbaik." (Q.S. Al Tin/95:4)

Ahsani Taqwim menurut sementara ulama adalah rupa terbaik. Ibn katsir menjelaskan bahwa ia bermakna sebaik-baik rupa (ahsanu suwar) .

Kata taqwiim berakar dari kata qawama yang bermakna kesempurnaan sesuatu sesuai dengan objeknya. Taqwiim bermakna menjadikan sesuatu memiliki qawaam, yaitu bentuk fisik yang sesuai dengan fungsinya. Kata ini digunakan untuk mengungkapkan keistimewaan manusia dibanding binatang, yaitu kelebihan akal, pemahaman dan bentuk fisik yang tegak lurus. Absani taqwiim menunjukkan bentuk fisik dan psikis yang sebaik-baiknya, yang menyebabkan manusia bisa melakukan fungsinya dengan sebaik mungkin. Sehingga dengan demikian absani taqwiim tidak sebatas pengertian fisik belaka.

${ }^{6}$ Sarnoto, Ahmad Zain Dan Fathoni, Ahmad. "Pendidikan Islam Berbasis Kecerdasan Majemuk". Madani Institute Volume 8 No. 2 (2019) 
Dalam penjelasan sebelumnya Gardner menyebut kecerdasan (intelligence) sebagai seperangkat kapasitas mapan, atau kecakapan mental. Sebagai kapasitas mental, kecerdasan berkembang secara dinamis, namun berkaitan erat dengan latar sosio-budaya dan dengan pendidikan dan pengasuhan. Hal ini memberikan gambaran bahwa setiap manusia memiliki kesempurnaan dan potensi yang didukung dari lingkungannya yang dinamis.

Kecakapan dan kecerdasan seseorang pada objek tertentu memiliki kecenderungan yang dibawanya. Hal ini mengafirmasi beragamnya kecerdasan majemuk memberikan peluang bagaimana manusia harus memiliki trial error dalam pembentukan dan pengenalan kecerdasan yang dimilikinya. Di sinilah sebenarnya kecenderungan yang dibawa sebagai kecerdasan, kapasitas dan kemampuan dasar sudah ada pada diri manusia.

Kecenderungan yang pada diri manusia inilah yang tersembunyi dan beragam antar satu dengan yang lain. Yang kemudian Gardner menyebutnya kecerdasan majemuk. Gardner hanya memberikan penjelasan tentang petunjuk dari orang yang memiliki dari sembilan kecerdasan yang dipopulerkannya itu mesti memiliki kemapanan mengkordinasi bagian-bagian yang membentuk kecerdasannya lebih tinggi dari yang lain. Meskipun, terdapat juga manusia yang memiliki lebih dari dua atau lebih kecerdasan.

Demikian, kecerdasan melekat pada kecederungan seseorang melakukan sesuatu. Kecenderungan untuk melakukan suatu dengan lebih baik dan cepat dari yang lain. Hal itu ditunjukkan dari kemampuannya pada kapasitas tertentu. Kecenderungan manusia inilah yang dipandang Islam sebagai fitrah atau bawaan yang terbaik. Abidin menyebut bahwa kecerdasan ganda sebelumnya dipopulerkan dalam pandangan Islam dengan penjelasan yang berbeda namun memiliki kesamaan tujuan dan praktik. Hal itu ditandai dari penekakan pada kemampuan-kemampuan mapan yang harus dimiliki oleh seorang muslim di antaranya; kecerdasan aqliyah, kecerdasan batiniyah, kecerdasan ijtimaiyah, kecerdasan jismiyah, kecerdasan akblaqiyah, kecerdasan rubiyah dan lainnya..?

Untuk itulah, pandangan Islam tentang kecerdasan majemuk tidaklah berseberangan. Pernyataan-pernyataan yang eksplisit yang telah lama diajarkan di dalam Islam inilah yang seharusnya diberikan keluasan dalam memahami secara kontekstual. Dengan begitu, pemahaman-pemahaman ini bisa memberikan kelapangan wawasan inteletual manusia.

7 Zainal Abidin. "Pengembangan Kecerdasan Majemuk (Multiple Intelligences) Di Madrasah.” Elementary Vol. 3 Edisi Juli-Desember (2017) 


\section{KESIMPULAN}

Kecerdasan majemuk yang dipopulerkan Gardner tidak berseberangan dengan pandangan Islam. Islam mengakui bahwa setiap manusia memiliki fitrah atau pembawaan yang terbaik. Kemampuan, kemapanan, dan bakat mengkordinasi manusia pada bagian tertentu yang menonjol dari sembilan kecerdasan yang berkembang. Hal tersebut menjelaskan pilihan manusia dalam menggali karakter yang dimilikinya adalah kecenderungan yang alami. Di sinilah kecenderungan yang telah lama ada ini membutuhkan dukungan yang dinamis sehingga dapat terasah dengan baik.

\section{Bibliografi}

Abidin, Zainal. Pengembangan Kecerdasan Majemuk (Multiple Intelligences) Di Madrasah. Elementary Vol. 3 Edisi Juli-Desember (2017)

Fadilah, Risydah. Pendidikan Islam Dan Kecerdasan Majemuk (Multiple Intelligence). Al-Irsyad: Jurnal Pendidikan dan Konseling Vol. 9, No. 2, Juni-Desember (2019)

Gunawan, Imam. Metode Penelitian Kualitatif Teori dan Praktik. Jakarta: Bumi Aksara. (2014).

Machali, Imam. Dimensi Kecerdasan Majemuk Dalam Kurikulum 2013. Insania, Vol. 19, No. 1, Januari - Juni (2014).

Sarnoto, Ahmad Zain Dan Fathoni, Ahmad. Pendidikan Islam Berbasis Kecerdasan Majemuk. Madani Institute Volume 8 No. 2 (2019)

H Izzati. 2021. Potensi Pembelajaran Manusia: Perspektif Neurosains Dan Islam. Alifbata: Jurnal Pendidikan Dasar

Jasminto. 2017. Konsep Pendidikan Anak Perspektif Fredrich Froebel, Proceedings Ancoms. UNHASY Tebuireng Jombang. 